\title{
Immunological Reconstitution Inflammatory Syndrome and Thrombotic Microangiopathy: Severe Complications in a Child With Acquired Immunodeficiency Syndrome
}

Clinical Pediatrics

2019, Vol. 58(9) 1022-1026

(C) The Author(s) 2019

Article reuse guidelines:

sagepub.com/journals-permissions DOI: 10.1 I 77/ $/ 0009922819852984$ journals.sagepub.com/home/cpj

@SAGE

\author{
Ana Paula Rocha, MD' ${ }^{10}$, Tiago Milheiro Silva, MD', Telma Francisco, MD', \\ Conceição Neves, MD', Vera Brites, MD', and Flora Candeias, MD'
}

\section{Introduction}

Some patients with human immunodeficiency virus (HIV) infection deteriorate shortly after starting highly active antiretroviral therapy (HAART), the so-called immunological reconstitution inflammatory syndrome (IRIS). ${ }^{1}$ Although having a spontaneous resolution in many instances, it can be fatal. ${ }^{1}$ Worse prognosis is seen in younger children, severe immunosuppression and central nervous system IRIS, or infections with specific agents, namely, Criptococcus. ${ }^{2}$ Hemophagocytic lymphohistiocytosis (HLH) has also been described in children with HIV infection, in the context of an immunological system dysregulation. ${ }^{3}$

Thrombotic microangiopathy (TMA) became rare with the introduction of HAART, being mostly associated with advanced disease. ${ }^{4}$ HIV-associated TMA has specific clinical aspects as well as a worse prognosis than idiopathic or congenital TMA. ${ }^{4-9}$

The authors present the case of a 10-month-old boy with advanced HIV infection who developed IRIS complicated with HLH and TMA during the course of his treatment.

\section{Case Report}

We report the case of a Caucasian boy whose mother had had negative third trimester HIV serology, who presented with axial hypotonia during the neonatal period, recurrent episodes of otitis media soon after, failure to thrive, and chronic diarrhea.

At 10 months of age, he was admitted to the intensive care unit and diagnosed with a Pneumocystis jiroveci pneumonia. Antibiotic treatment was started with ceftriaxone (100 mg/kg/day), vancomycin ( $40 \mathrm{mg} / \mathrm{kg} /$ day), azithromycin (10 mg/kg/day), and cotrimoxazole (15 mg/kg/day), as well as methylprednisolone ( $2 \mathrm{mg} / \mathrm{kg} /$ day $)$. The bronchoalveolar lavage also revealed positive polymerase chain reaction (PCR) for parainfluenza 3. HIV serology was positive for HIV-1. Both parents were tested and were also positive, bringing to light a diagnosis of mother-to-child HIV transmission.

Lumbar puncture was performed and the cytological examination was unremarkable, with positive parvovirus B19 PCR and cerebrospinal fluid (CSF) HIV viral load of 98 viral copies/mL. Parvovirus B19 blood PCR was also positive.

The child's initial viral load was 1460000 viral copies $/ \mathrm{mL}$, and the $\mathrm{CD}^{+}$cell count was 9 cells $/ \mu \mathrm{L}$ (Table 1). Low resistance to abacavir was identified (mutation M184MV); HLA B*5701 was negative. He was transferred to the infectious diseases ward, and at day 5 of treatment with cotrimoxazole, HAART was started with lamivudine ( $4 \mathrm{mg} / \mathrm{kg} / \mathrm{dose} 2 \mathrm{id}$ ), zidovudine $(12 \mathrm{mg} / \mathrm{kg} / \mathrm{dose} 2 \mathrm{id})$, and lopinavir/ritonavir $\left(230 \mathrm{mg} / \mathrm{m}^{2} /\right.$ dose of lopinavir $\left.2 \mathrm{id}\right)$; prophylactic azithromycin $20 \mathrm{mg} / \mathrm{kg} /$ dose once weekly was also prescribed.

On the second week of HAART, recurrent vomiting and transaminases elevation occurred (maximum at day 15 of HAART: aspartate transaminase $283 \mathrm{U} / \mathrm{L}$, alanine transaminase $221 \mathrm{U} / \mathrm{L}$; Table 1). Concomitantly, he started having low-grade fever, which persisted afterward. Corticosteroid dose (for Pneumocystis jiroveci) had been reduced 3 days before the beginning of symptoms.

'Hospital Dona Estefânia, Centro Hospitalar Lisboa Central, Lisboa, Portugal

Corresponding Author:

Ana Paula Rocha, Unidade de Infecciologia, Serviço de Pediatria, Hospital Dona Estefânia, Rua Jacinta Marto, I I69-045 Lisboa, Portugal.

Email: paulasacrocha@gmail.com 
Table I. Blood Tests Evolution.

\begin{tabular}{|c|c|c|c|c|c|}
\hline Blood Tests & $\begin{array}{l}\text { Beginning of } \\
\text { HAART }\end{array}$ & $\begin{array}{l}2 \text { Weeks } \\
\text { of HAART/ } \\
\text { Beginning of } \\
\text { Symptoms }\end{array}$ & $\begin{array}{l}\text { I Month of } \\
\text { HAART }\end{array}$ & $\begin{array}{l}21 / 2 \text { Months } \\
\text { of HAART }\end{array}$ & $\begin{array}{l}3 \text { Months of } \\
\text { HAART }\end{array}$ \\
\hline CD4 count $(/ \mu \mathrm{L})$ & 9 & 109 & 54 & 59 & 88 \\
\hline Viral load (copies/mL) & 460000 & 3280 & 139 & 117 & 132 \\
\hline $\mathrm{Hb}(10.5-13.4 \mathrm{~g} / \mathrm{L})$ & 12.2 & 8.6 & 7.6 & 8.9 & 4.2 \\
\hline WBC $\left(6-16 \times 10^{9} / L\right)$ & 2.28 & 2.60 & 8.1 & 17 & 9.7 \\
\hline Neutrophils $\left(0.1-1.0 \times 10^{9} / \mathrm{L}\right)$ & 6.56 & 0.97 & 6.05 & 12.6 & 7.5 \\
\hline Platelets $\left(200-500 \times 10^{9} / \mathrm{L}\right)$ & 335 & 68 & 107 & 21 & 8 \\
\hline Reticulocytes (0.5\% to $2.5 \%$ ) & - & - & 9.42 & 14 & 2.25 \\
\hline Fibrinogen (1.5-3.19 g/L) & - & 0.8 & 0.7 & 1.0 & 0.5 \\
\hline TP $(10.6-11.4 \mathrm{~s}) / \mathrm{INR}$ & - & $18.7 / 1.63$ & $12.6 / 1.13$ & $15.4 / 1.36$ & $21.1 / 1.83$ \\
\hline APTT (24-36 s) & - & 33.8 & 26.0 & 24.7 & III.6 \\
\hline $\begin{array}{l}\text { Ferritin }(8.4-81.9 \mathrm{ng} / \mathrm{mL}) \text {; } \\
\text { SI: } 18-184 \mathrm{pmol} / \mathrm{L}\end{array}$ & - & $1194(2683)$ & $667(1498)$ & 734 (1649) & $2530(5685)$ \\
\hline $\operatorname{ESR}(<\mathrm{II} \mathrm{mm} / \mathrm{h})$ & 60 & 4 & 4 & 5 & 9 \\
\hline CRP ( $<5 \mathrm{mg} / \mathrm{L}) ; \mathrm{SI}: 47.6 \mathrm{nmol} / \mathrm{L}$ & $1.2(11.4)$ & 191 (1828) & $3.4(32.38)$ & $5(47.6)$ & $0.6(5.7)$ \\
\hline $\begin{array}{l}\text { AST }(20-67 \mathrm{U} / \mathrm{L}) \\
\text { SI: } 0.33-1.12 \mu \mathrm{moL} /(\mathrm{s} . \mathrm{L})\end{array}$ & $62(1.03)$ & $283(4.7)$ & $15(0.25)$ & $40(0.67)$ & $61(1.02)$ \\
\hline $\begin{array}{l}\text { ALT }(5-33 \mathrm{U} / \mathrm{L}) \\
\text { SI: } 0.08-0.55 \mu \mathrm{moL} /(\mathrm{s} . \mathrm{L})\end{array}$ & $56(0.93)$ & $221(3.68)$ & $7(0.12)$ & $19(0.32)$ & $18(0.3)$ \\
\hline $\begin{array}{l}\text { LDH (I 63-452 U/L); } \\
\text { SI: } 2.72-7.53 \mu \mathrm{moL} /(\mathrm{s} . \mathrm{L})\end{array}$ & $558(9.3)$ & - & $224(3.73)$ & $586(9.76)$ & $1748(29.1)$ \\
\hline $\begin{array}{l}\text { Bilirrubin }(0.2-1.2 \mathrm{mg} / \mathrm{dL}) \\
\text { SI: } 3.4-20.5 \mu \mathrm{mol} / \mathrm{L}\end{array}$ & $0.11(1.88)$ & - & $0.45(7.69)$ & $0.24(4.1)$ & 1.15 (19.66) \\
\hline $\begin{array}{l}\text { Triglycerides }(<178 \mathrm{mg} / \mathrm{dL}) \\
\text { SI: }<2 \mathrm{mmol} / \mathrm{L}\end{array}$ & $259(2.92)$ & $190(2.15)$ & - & $277(3.13)$ & $317(3.6)$ \\
\hline $\begin{array}{l}\text { Urea }(10.9-36 \mathrm{mg} / \mathrm{dL}) \\
\text { SI: } 3.9-12.85 \mathrm{mmol} / \mathrm{L}\end{array}$ & $13(2.16)$ & $5(0.83)$ & $18(2.99)$ & $55(9.16)$ & $103(17.14)$ \\
\hline $\begin{array}{l}\text { Creatinine }(0.1-0.36 \mathrm{mg} / \mathrm{dL}) \text {; } \\
\text { SI: } 0.01-0.03 \mathrm{mmol} / \mathrm{L}\end{array}$ & $0.43(0.04)$ & $0.3(0.03)$ & $0.202(0.02)$ & $0.20(0.02)$ & $0.32(0.03)$ \\
\hline $\begin{array}{l}\text { Haptoglobin }(0.3-2.0 \mathrm{~g} / \mathrm{L}) \text {; } \\
\text { SI: } 3-20 \mu \mathrm{mol} / \mathrm{L}\end{array}$ & - & - & $0.98(9.8)$ & $0.07(0.7)$ & $<0.07(<0.7)$ \\
\hline $\begin{array}{l}\text { ADAMTSI } 3 \text { activity } \\
(>0.67 \mathrm{UI} / \mathrm{ML}) / \text { antibody } \\
(<\mathrm{I} \mathrm{UI} / \mathrm{mL})\end{array}$ & - & - & $0.6 / 0.57$ & $0.17 / 1.63$ & $0.19 /-$ \\
\hline Blood smear & - & - & Rare schizocytes & Schizocytes & Schizocytes \\
\hline $\begin{array}{l}\text { Soluble CD25 } \\
\text { (458-I I } 97 \mathrm{pg} / \mathrm{mL})\end{array}$ & - & 22167 & 2410 & - & \\
\hline Infectious agents & $\begin{array}{l}\text { Pneumocystis } \\
\text { jiroveci, } \\
\text { parainfluenza 3, } \\
\text { parvovirus BI9 } \\
\text { (blood and CSF- } \\
\text { positive PCR) }\end{array}$ & Parainfluenza 3 & $\begin{array}{c}\text { Klebsiella } \\
\text { pneumoniae } \\
\text { ESBL (duodenal } \\
\text { biopsy) }\end{array}$ & - & - \\
\hline
\end{tabular}

Abbreviations: APTT, activated partial thromboplastin time; ALT, alanine transaminase; AST, aspartate transaminase; CRP, C-reactive protein; CSF, cerebrospinal fluid; ESR, erythrocyte sedimentation rate; ESBL, extended-spectrum $\beta$-lactamase; HAART, highly active antiretroviral therapy; $\mathrm{Hb}$, hemoglobin; INR, international normalized ratio; LDH, lactate dehydrogenase; PCR, polymerase chain reaction; SI, International System of Units; TP, prothrombin time; WBC, white blood cell.

Opportunistic agents were excluded (Table 2), with negative blood, urine, and CSF culture; respiratory secretions were positive for parainfluenza 3. Catheter sepsis was assumed and hence cefotaxime $(150 \mathrm{mg} / \mathrm{kg} /$ day $)$, gentamicin $(5 \mathrm{mg} / \mathrm{kg} /$ day $)$, and vancomycin $(40 \mathrm{mg} / \mathrm{kg} /$ day $)$ were started and the catheter removed. 
Table 2. Infectious Agents Tested and Its Results.

\begin{tabular}{|c|c|c|}
\hline Agent & Result & Samples/Tests \\
\hline Herpes simplex 1 and 2 & Negative & Blood, CSF, and gastric/duodenal biopsies' PCR \\
\hline Herpes hominis 6 and 7 & Negative & Blood, CSF, and gastric/duodenal biopsies' PCR \\
\hline Cytomegalovirus & Negative & Blood, urine, gastric/duodenal, and CSF viral load; blood serology \\
\hline Varicella zoster virus & Negative & Blood and CSF PCR; blood serology \\
\hline Epstein-Barr virus & Negative & Blood and CSF PCR; blood serology \\
\hline \multirow[t]{2}{*}{ Parvovirus BI9 } & Negative & Blood and CSF PCR \\
\hline & Positive & IgG in blood serology \\
\hline Adenovirus & Negative & Blood, respiratory tract secretions, and feces PCR \\
\hline Enterovirus & Negative & Feces and respiratory secretions PCR \\
\hline Rotavirus & Negative & Feces PCR \\
\hline Norwalk virus & Negative & Feces PCR \\
\hline Astrovirus & Negative & Feces PCR \\
\hline Mycobacteria & Negative & $\begin{array}{l}\text { Gastric juice, CSF and biopsies' cultural examination, direct } \\
\text { examination, and PCR; IGRA T-spot }\end{array}$ \\
\hline \multirow[t]{2}{*}{ Clostridium difficile } & Positive & Feces antigen \\
\hline & Negative & Feces toxin \\
\hline Yersinia enterocolitica & Negative & Feces \\
\hline Escherichia coli OI57 & Negative & Feces \\
\hline Pneumocystis jiroveci & Negative & Respiratory secretions PCR \\
\hline Cryptococcus neoformans & Negative & CSF and blood antigen \\
\hline Aspergillus & Negative & Galactomannan \\
\hline Cryptosporidium & Negative & Antigen and staining in feces \\
\hline Toxoplasma gondii & Negative & Blood serology \\
\hline Isospora belli & Negative & Staining in feces \\
\hline Giardia lamblia & Negative & Feces and biopsies' antigen \\
\hline Leishmania & Negative & Blood serology \\
\hline
\end{tabular}

Abbreviations: CSF, cerebrospinal fluid; PCR, polymerase chain reaction; IgG, immunoglobulin G; IGRA, interferon- $\gamma$ release assay.

At this point, he started having bloody and mucous diarrhea, hepatosplenomegaly, a macular rash, and stupor. $\mathrm{CD}^{+}$cell count was 109 cells $/ \mu \mathrm{L}$ (a $1200 \%$ increase over the basal number, 2 weeks after beginning of HAART). Symptoms and laboratory studies were suggestive of HLH (Table 1), and no infectious agents besides parainfluenza 3 were identified.

Methylprednisolone $2 \mathrm{mg} / \mathrm{kg} / \mathrm{day}$ and intravenous immunoglobulin were initiated, with slight temporary clinical and laboratory improvement (Table 1), but diarrhea, stupor, and weight loss persisted, with severe hypoalbuminemia and edema. Nephrotic range proteinuria was present, attributed to a multifactorial process including iatrogenic (HAART and nephrotoxic antibiotic) and possible HIV nephropathy. Cardiac and ophthalmological evaluations were normal, as well as brain magnetic resonance imaging. Upper gastrointestinal endoscopy revealed Alcian blue/periodic acid-Schiff negative clear-cytoplasm enterocytes and identified a Klebsiella pneumoniae ESBL + (extended-spectrum $\beta$-lactamase positive) on duodenal biopsy.

One month after beginning of HAART, clinical deterioration occurred with new-onset regenerative anemia with a hemoglobin of $7.6 \mathrm{~g} / \mathrm{L}$, reticulocytosis $(9.42 \%)$, and schizocytes on blood smear, with no other signs of hemolysis, and ADAMTS13 activity and antigen were within normal range (Table 1). Opportunistic agents were again excluded, as described before. Hemolysis occurred at $2^{1 / 2}$ months after HAART initiation, in the context of thrombotic microangiopathy, with normal renal function and ADAMTS13 activity decrease (Table 1). Plasma infusion was initiated with no response, after which the patient was put on daily plasma exchange ( 1.5 times the patient's volemia) for 2 weeks, but subsequent worsening with recurrent fever and poor skin perfusion occurred. Opportunistic agents were once more excluded and he was again started on antimicrobials (cefotaxime $150 \mathrm{mg} / \mathrm{kg} /$ day, vancomycin $40 \mathrm{mg} / \mathrm{kg} /$ day, gentamycin $5 \mathrm{mg} / \mathrm{kg} /$ day, later changed to meropenem $60 \mathrm{mg} / \mathrm{kg} /$ day, vancomycin $40 \mathrm{mg} / \mathrm{kg} /$ day, amphotericin B $3 \mathrm{mg} / \mathrm{kg} /$ day, ganciclovir $10 \mathrm{mg} / \mathrm{kg} /$ day, and paromomycin $30 \mathrm{mg} / \mathrm{kg} /$ day), but unfortunately, the child died from massive intestinal bleeding in the context of intravascular disseminated coagulation, at 14 months of age (Table 1). The patient's family declined autopsy. 


\section{Discussion}

This case is remarkable for the description of a pediatric age IRIS, and for the nowadays' rarely seen HIVassociated MAT (maximally assisted therapy). Also, this patient had some "red flags" before Pneumocystis jiroveci pneumonia unmasked the final diagnosis, namely, recurrent bacterial infections (recurrent otitis media), failure to thrive, chronic diarrhea, and neurological dysfunction. ${ }^{10}$

The clinical paradoxical worsening soon after HAART initiation, with no other cause identified and despite an increase in CD4 count and decreasing viral load, ${ }^{1}$ was attributed to an IRIS, although it is hard to be sure about the trigger agent. This is mostly described in adults and it is thought to be due to the dysregulated recovery of the immune response to viable and nonviable pathogens, ${ }^{11,12}$ mostly mycobacterial and fungal, ${ }^{11-13}$ and pediatric cohorts also refer Varicella-zoster virus as a common cause. ${ }^{13}$

Parvovirus B19 PCR was also positive in both blood and CSF, which raises the question of whether it could be the IRIS causative agent. Some reports present IRIS in the context of parvovirus B19 infection. ${ }^{14,15}$ Also, parainfluenza 3 was still positive in respiratory tract secretions.

No evidence of cytomegalovirus primoinfection was found, but the patient was treated empirically with ganciclovir and, in light of the severe course, also with paromomycin for a possible undiagnosed cryptosporidium infection.

This patient had many risk factors for IRIS: young age, close proximity to the diagnosis of an infection/ opportunistic infection (parvovirus B19, parainfluenza 3 , and Pneumocystis jiroveci in our case), earlier initiation of HAART after starting antimicrobial treatment, and very low $\mathrm{CD} 4{ }^{+} \mathrm{T}$ cells number before therapy. ${ }^{11-13}$

In the context of IRIS, he had HLH criteria (Table 1) and he improved with methylprednisolone dose increase and intravenous immunoglobulin.

TMA, namely, thrombotic thrombocytopenic purpura (TTP), is a rare HIV complication in the post-HAART era. ${ }^{4,8}$ In our case, the advanced HIV disease and the only moderately decreased ADAMTS13 level were suggestive of a viral-mediated process on the endothelium with ADAMTS13 consumption, rather than ADAMTS13 antibody-mediated depletion. ${ }^{4-6}$ Because of this, some authors advocate that HIV-related TMA usually responds less favorably to plasma exchange than idiopathic $\mathrm{TTP}^{4,5,9}$ so plasma infusion was our first choice for treatment. On the other hand, our patient had massive intestinal losses, so we could not be sure about the mechanism involved, as ADAMTS13 antibodies would probably have been lost this way. Still, HIV-associated TMA/TTP has sparse response to any treatment approach and very poor prognosis. ${ }^{6-8}$

Blood smear showing rare schizocytes early in the course of the hospital admission, a frequent finding in HIV-infected patients, ${ }^{4}$ was probably an early sign of virus-mediated endothelium damage.

This case has many pitfalls as clinical and laboratorial signs were clearly multifactorial. Weight loss and anemia, for instance, could be the result of the HIV wasting syndrome, chronic severe disease, and, later, hemolysis, with weight loss aggravated by hypoalbuminemia due to renal losses and/or to the severe diarrhea. On the other hand, persistent diarrhea was a challenge as it could have several causes: HIV intestinal tissue infection, intestinal involvement with microangiopathy, antiretroviral toxicity, or infectious agents.

Still, we believe our case report is valuable for the description of a case of HIV-associated TMA, a rare complication in the post-HAART era.

\section{Author Contributions}

APR - conception of the work/writing of the case, acquisition of data for the work, analysis and review of intelectual content, ensuring the accuracy of the work. TMS, TF, CN, VB, FC acquisition of data for the work, analysis and review of intelectual content, ensuring the accuracy of the work.

\section{Declaration of Conflicting Interests}

The author(s) declared no potential conflicts of interest with respect to the research, authorship, and/or publication of this article.

\section{Funding}

The author(s) received no financial support for the research, authorship, and/or publication of this article.

\section{Informed Consent}

Written informed consent was provided by the legally authorized representative.

\section{ORCID iD}

Ana Paula Rocha (iD) https://orcid.org/0000-0001-6594-4772

\section{References}

1. French MA, Lenzo N, John M, et al. Immune restoration disease after the treatment of immunodeficient HIVinfected patients with highly active antiretroviral therapy. HIV Med. 2000;1:107-115.

2. Boulware DR, Callens S, Pahwa S. Pediatric HIV immune reconstitution inflammatory syndrome (IRIS). Curr Opin HIV AIDS. 2008;3:461-467. 
3. Tolani D, Sha I. Hemophagocytic lymphohistiocytosis in an infant with probable HIV infection. Indian $J$ Sex Transm Dis AIDS. 2013;34:152-153.

4. Brecher ME, Hay SN, Park YA. Is it HIV TTP or HIVassociated thrombotic microangiopathy? J Clin Apher. 2008;23:186-190.

5. Warner NC, Vaughan LB, Wenzel RP. Human immunodeficiency virus associated thrombotic thrombocytopenic purpura, a clinical conundrum. J Clin Apher. 2017;32: 567-570.

6. Miller RF, Scully M, Cohen H, et al. Thrombotic thrombocytopenic purpura in HIV-infected patients. Int $J$ STD AIDS. 2005;16:538-542.

7. Saab KR, Elhadad S, Copertino D, Laurence J. Thrombotic microangiopathy in the setting of HIV infection: a case report and review of the differential diagnosis and therapy. AIDS Patient Care STDS. 2016;30:359-464.

8. Becker S, Fusco G, Fusco J, et al; Collaborations in HIV Outcomes Research/US Cohort. HIV associated thrombotic microangiopathy in the ERA of highly active antiretroviral therapy: an observational study. Clin Infect Dis. 2004;39(suppl 5):S267-S275.

9. Park YA, Hay SN, Brecher ME. ADAMTS13 activity levels in patients with human immunodeficiency virus-associated thrombotic microangiopathy and profound CD4 deficiency. J Clin Apher. 2009;24:32-36.

10. Burchett SK, Pizzo PA. HIV infection in infants, children, and adolescents. Pediatr Rev. 2003;24:186-194.

11. Wilson EM, Sereti I. Immune restoration after antiretroviral therapy: the pitfalls of hasty or incomplete repairs. Immunol Rev. 2013;254:343-354.

12. Murdoch DM, Venter WD, Van Rie A, Feldman C. Immune reconstitution inflammatory syndrome (IRIS): review of common infectious manifestations and treatment options. AIDS Res Ther. 2007;4:9.

13. Puthanakit T, Oberdorfer P, Akarathum N, Wannarit $\mathrm{P}$, Sirisanthana T, Sirisanthana V. Immune reconstitution syndrome after highly active antiretroviral therapy in human immunodeficiency virus-infected Thai children. Pediatr Infect Dis J. 2006;25:53-58.

14. Nolan RC, Chidlow G, French MA. Parvovirus B19 encephalitis presenting as immune restoration disease after highly active antiretroviral therapy for human immunodeficiency virus infection. Clin Infect Dis. 2003;36:1191-1194.

15. Intalapaporn P, Poovorawan Y, Suankratay C. Immune reconstitution syndrome associated with parvovirus B19induced pure red cell aplasia during highly active antiretroviral therapy. J Infect. 2006;53:e79-e82. 